
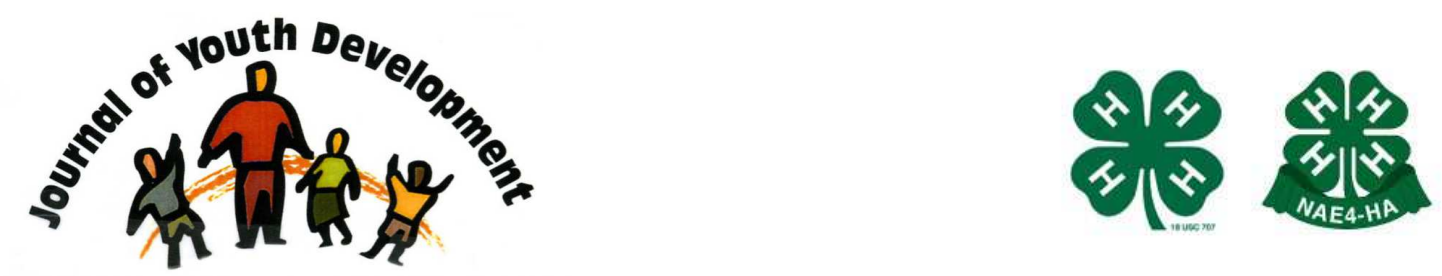

Bridging Research \& Practice

\title{
Public Opinions of Youth Development Programs
}

\author{
Scott D. Scheer \\ The Ohio State University \\ Columbus, $\mathrm{OH}$ \\ scheer.9@osu.edu \\ Joseph F. Donnermeyer \\ The Ohio State University \\ Columbus, $\mathrm{OH}$
}




\title{
JOURNAL OF YOUTH DEVELOPMENT \\ bridging research and practice

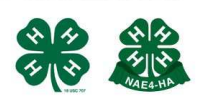

Volume 1, Number 3, Winter 2006-2007

Article 0603FA001

\section{Public Opinions of Youth Development Programs}

\author{
Scott D. Scheer and Joseph F. Donnermeyer \\ The Ohio State University
}

\begin{abstract}
A state-wide survey was conducted in a Midwestern state with randomly selected adults $(n=1229)$ to determine their perceptions of youth program importance, effectiveness, and activity structure (competitive and/or cooperative). Public opinion was overwhelmingly supportive in describing youth programs as "very important" (64.5\%) for promoting youth development. However, indications of program effectiveness for preventing adolescent problem behaviors $(55.5 \%$ "somewhat effective") were not as strong. In addition, cooperativestructured activities (74.8\%) were preferred over competitive-oriented activities (16.7\%) as having more positive results for youth development. Implications for practitioners, policy makers, and social scientists are discussed.
\end{abstract}

\section{Public Opinions of Youth Development Programs}

Programs for youth in non-school settings have been part of the U.S. non-formal educational system for over 100 years and have been examined extensively for promoting positive youth development in terms of asset building, resiliency, problem prevention, risk and protective factors, strategies for success, and theoretical frameworks for community youth development (Benson, 1997; Catalano, Berglund, Ryan, Lonczak, \& Hawkins, 2004; Deschenes, McDonald, McLaughlin, 2004; Kress, 2004; National Research Council and Institute of Medicine, 2002; Perkins \& Borden, 2003; Pittman, Irby, \& Ferber, 2000; Roth, Brooks-Gunn, Murray, \& Foster, 1998; Small \& Memmo, 2004; Scheer, 1997). Successful youth programs have been identified as those that not only target development of problem-free youth, but also prepare youth to be fully engaged in society (Perkins, Borden, \& Villarruel, 2001; Pittman, Irby, \& Ferber, 2000).

While there has been extensive research concerning youth development programs and other studies examining adult beliefs toward adolescents and their ability to contribute to their communities (Hein, 1998; Zeldin \& Topitzes, 2002), there has been a lack of research-based 
information about public perceptions of youth programs for positive youth development. The support of the general public is important for youth programs, as are parent(s) of children who participate in programs, donors, or others who are directly involved. As such, public opinion is much like any other stakeholder group in influencing which programs are socially acceptable (Donnermeyer, 2000). Therefore, as practitioners, policy makers, and prevention scientists work toward practical models of positive youth development, the public's support for youth programs will be essential for future funding, community involvement, and ultimately, program sustainability. The synergy between youth and communities has been suggested by Pittman (2006) as the next paradigm shift: "from youth participation for youth development to youth contributing to communities and communities supporting youth as partnerships for community change" (p. 20).

Since positive public opinion of youth programs is hypothesized as a key catalyst for successful youth outcomes in communities, it is also relevant to determine public beliefs about program activity structure for positive youth development. One key question is the type of activities the general public finds acceptable and prefer. American cultural values emphasize competition, but this preference is tempered by concerns about the fairness of competition, as evidenced by recent news headlines about cheating by a few coaches, parents, youth advisors, and youth participants (Alder, 2006; Callahan, 2004). In addition, leaders of both school and non school youth programming do not design and implement activities in a vacuum. There are many stakeholders beyond youth themselves who potentially influence, for better or worse, the type, quantity and longevity of youth programs, including parents/guardians, volunteer helpers, school, church, political and other leaders at the local, state, and national levels, and the general public itself.

Regardless of how much so-called "science" forms the foundation of youth development programs, public perceptions affect the local and national political context in which these programs must operate (Donnermeyer, 2000). For this reason, we focus on the general public as one important stakeholder group. Further, it is one for which little or no research has been completed. Therefore, the purpose of this study is to examine public opinions of youth programs in a Midwestern state for their perceptions of program importance, effectiveness, and activity structure (competitive and/or cooperative).

\section{Sample}

\section{Methods}

The population for this study is all state-wide citizens who are of voting age ( $>18$ years of age). The sampling frame consisted of 1,500 respondents selected through the random digit dialing method for telephone surveys utilized by a research one university survey research center. The sample was constructed to be generalizable across the state for sex, location, and ethnicity.

A final sample of 1229 adults from throughout a Midwestern state was surveyed. Sixty percent of the sample were female and $40 \%$ were male. Demographic characteristics reported most frequently are as follows: respondents were 39 year old or younger (31.2\%), married (58.8\%); high school graduates (34.5\%), live in a small town or village that is not next to a city of 50,000 or more persons $(32.1 \%)$, household income between $\$ 26,000-\$ 50,000(33.1 \%)$, and Caucasian/white $(90.5 \%)$. Refer to Table 1 for specific demographic characteristics for the study's sample. 
Table 1

Sample Description

\begin{tabular}{|c|c|c|c|c|}
\hline 1212 Respondents & $\begin{array}{r}60 \% F \\
(n=\end{array}$ & $\begin{array}{l}\text { iales } \\
\text { 8) }\end{array}$ & $\begin{array}{l}40 \% \\
(n=\end{array}$ & $\begin{array}{l}\text { Males } \\
\text { 91) }\end{array}$ \\
\hline Age & $<40$ years & $40-49$ years & $50-59$ years & $>59$ years \\
\hline & $\begin{array}{c}31.2 \% \\
(n=382)\end{array}$ & $\begin{array}{c}23.4 \% \\
(n=286)\end{array}$ & $\begin{array}{c}18.2 \% \\
(n=223)\end{array}$ & $\begin{array}{c}27.1 \% \\
(n=332)\end{array}$ \\
\hline Marital Status & Married & $\begin{array}{l}\text { Divorced/ } \\
\text { Separated }\end{array}$ & $\begin{array}{c}\text { Single/ } \\
\text { Never Married }\end{array}$ & Widow(er) \\
\hline & $\begin{array}{c}58.8 \% \\
(n=722)\end{array}$ & $\begin{array}{c}12.5 \% \\
(n=153)\end{array}$ & $\begin{array}{c}19.0 \% \\
(n=233)\end{array}$ & $\begin{array}{c}9.8 \% \\
(n=120)\end{array}$ \\
\hline Education & $\begin{array}{l}\text { Less than high } \\
\text { school diploma }\end{array}$ & $\begin{array}{l}\text { High School } \\
\text { Graduates }\end{array}$ & $\begin{array}{l}\text { Some College } \\
\text { or 2-Yr. Degree }\end{array}$ & $\begin{array}{c}\text { College } \\
\text { Graduates }\end{array}$ \\
\hline & $\begin{array}{c}10.8 \% \\
(n=133)\end{array}$ & $\begin{array}{c}34.5 \% \\
(n=424)\end{array}$ & $\begin{array}{c}28.6 \% \\
(n=351)\end{array}$ & $\begin{array}{c}26.1 \% \\
(n=320)\end{array}$ \\
\hline Place of Residence & City & Suburb of city & $\begin{array}{c}\text { Small town or } \\
\text { village }\end{array}$ & $\begin{array}{c}\text { Farm/ } \\
\text { open country }\end{array}$ \\
\hline & $\begin{array}{c}19.1 \% \\
(n=235)\end{array}$ & $\begin{array}{c}26.4 \% \\
(n=324)\end{array}$ & $\begin{array}{c}32.1 \% \\
(394)\end{array}$ & $\begin{array}{c}22.4 \% \\
(n=275)\end{array}$ \\
\hline Household income & $\$ 25,000$ or less & $\begin{array}{c}\$ 26,000- \\
\$ 50,000\end{array}$ & $\begin{array}{l}\$ 51,000- \\
\$ 75,000\end{array}$ & $\begin{array}{l}\$ 76,000- \\
\text { and above }\end{array}$ \\
\hline & $\begin{array}{c}25.7 \% \\
(234)\end{array}$ & $\begin{array}{c}33.1 \% \\
(301)\end{array}$ & $\begin{array}{c}22.4 \% \\
(204)\end{array}$ & $\begin{array}{c}18.7 \% \\
(n=170)\end{array}$ \\
\hline Ethnicity & $\begin{array}{l}\text { Caucasian/ } \\
\text { white }\end{array}$ & $\begin{array}{r}\text { African } A \\
\text { bla }\end{array}$ & $\begin{array}{l}\text { nerican/ } \\
\text { k }\end{array}$ & $\begin{array}{c}\text { Other } \\
\text { ethnicities }\end{array}$ \\
\hline & $\begin{array}{c}90.5 \% \\
(n=90.5 \%)\end{array}$ & $\begin{array}{l}6.4 \\
(n=\end{array}$ & & $\begin{array}{c}3.0 \% \\
(n=37)\end{array}$ \\
\hline
\end{tabular}

\section{Measures}

Procedures as established by Dillman $(1978 ; 2000)$ for developing telephone survey questions were followed. Standard survey questions were used to measure the demographic variables of sex, age, place of residence, household income, ethnicity, education, and marital status. The youth development program questions were measured with five Likert-type items.

For "importance" of youth programs, the sample was asked, "How important is it for youth to participate in non-school youth programs that promote youth development, such as Boy/Girl Scouts, 4-H, and Girls Clubs?" Response categories were, "very important," "somewhat important," "not very important," and "not important at all." 
For "effectiveness" in youth programs to prevent problems behaviors, respondents were asked, "How effective are non-school youth programs in preventing adolescent problem behaviors of crime, delinquency, or drug use?" Response categories were, "very effective," "somewhat effective," "not very effective," and "not at all effective."

For "activity environment or program structure," the adults were asked, "which of the two programs will have the most positive results - competitive programs or cooperative programs?" To further understand beliefs about program structure in regards to positive youth development, respondents were asked, "how likely is it that programs in which children compete against each other will result in positive development?" and "how likely is it that programs in which children work together on something will result in positive development?" Both questions had response categories of, "very likely," "somewhat likely," and "not very likely."

\section{Descriptive Statistics}

\section{Results}

Results targeted public perceptions of youth development in terms of importance, effectiveness, and activity structure (competitive - cooperative). For importance, respondents were asked about how important it was for youth to participate in non-school youth programs that promote youth development. Most of the sample $(64.5 \%, n=782)$ believed it was "very important." See Table 2.

Table 2

Frequency and percent values for perceptions of importance of youth participation in non-school programs

\begin{tabular}{|l|c|c|}
\hline Descriptor & Frequency & Percent \\
\hline Very important & 782 & 64.5 \\
\hline Somewhat important & 359 & 29.6 \\
\hline Not very important & 49 & 4.0 \\
\hline Not at all important & 22 & 1.8 \\
\hline
\end{tabular}

Note. Total $\mathrm{n}=1212$

Minimal demographic variations were found for the variables of sex, age, income, education, and race according to the percent of respondents who perceived youth development programs as "very important" (most frequently reported perception), for promoting youth development. The percent values for sex ranged from $67.9 \%$ (females) to $59.5 \%$ (males), for age ranged from $67.9 \%$ (60 and older) to $62.4 \%$ (39 and younger), for household income $60.4 \%$ ( $\$ 76,000$ or more) to $65.5 \%$ ( $\$ 25,000$ or less), for education $68.6 \%$ (some college/two-year degree) to $61.2 \%$ (less than high school), and for race $72 \%$ (African American/black) to $63.9 \%$ (other), white/Caucasian was 64\%. Demographics for the "importance" of youth development program variables with differences greater than $10 \%$ were martial status and location. For perceptions of "very important" for youth to participate in non-school youth development programs, martial status variable ranged from $74.2 \%$ (divorced/separated) to $56.1 \%$ (single/never married), and the location variable ranged from $69.9 \%$ (farm/open country) to $57.6 \%$ (suburb of city).

For effectiveness, the sample was asked how effective are non-school programs in preventing adolescent problems behaviors of crime, delinquency, or drug use? Over half of the sample $(55.5 \%, n=643)$ believed that non-school programs are "somewhat effective", while about a third perceived non-school programs as "very effective." See Table 3. 
Table 3

Frequency and percent values for perceptions of effectiveness of non-school youth programs in preventing adolescent problem behaviors

\begin{tabular}{|l|c|c|}
\hline Program Structure & Frequency & Percent \\
\hline Very effective & 381 & 32.9 \\
\hline Somewhat effective & 643 & 55.5 \\
\hline Not very effective & 101 & 8.7 \\
\hline Not at all effective & 34 & 2.9 \\
\hline
\end{tabular}

Note. Total $\mathrm{n}=1229$

Minimal demographic variations were found for the variables of sex, age, martial status and race according to the percent of respondents who perceived these youth programs as "somewhat effective" (most frequently reported perception) in preventing adolescent problem behaviors. Demographics for the "effectiveness" of youth programs with differences greater than $10 \%$ were household income, education, and location. For "somewhat effective" perceptions of youth programs in preventing problem behaviors, the income variable ranged from $63.0 \%$ ( $\$ 76,000$ or more) to $50.7 \%$ ( $\$ 25,000$ or less), education ranged from $57.8 \%$ (four-year degree/graduate school) to $44.5 \%$ (less than high school), and location ranged from $62.7 \%$ (suburb of city) to $47.5 \%$ (city).

Three questions were used to determine the type of program structure (competitive, cooperative) that is best to promote positive development. The first question asked respondents which type of program will have the most positive results (i.e., for youth development and problem behavior prevention). Almost three-fourths of the sample $(74.8 \%, n=882)$ indicated cooperative programs would bring about positive results. See Table 4. Minimal demographic variations (less than $10 \%$ ) were found for those respondents who indicated cooperativestructured programs as having the most positive results for youth development, except for the sex variable. More females (79.1\%) than males (68.4\%) selected cooperative programs for having the most positive results.

Table 4

Frequency and percent values for perceptions of program structure type to promote positive youth outcomes

\begin{tabular}{|l|c|c|}
\hline Program Structure & Frequency & Percent \\
\hline Cooperative Activities & 882 & 74.8 \\
\hline Competitive Activities & 197 & 16.7 \\
\hline Cooperative/Competitive Activities & 100 & 8.5 \\
\hline
\end{tabular}

Note. Total $\mathrm{n}=1229$

The two other questions inquired into how likely is it those programs in which children compete against each other or work together on something will result in positive youth development. A little over a quarter of the sample $(26.3 \%, n=314)$ reported that it was "very likely" that competitive programs resulted in positive development (Figure 1), in comparison to $68.5 \%(n=$ 831 ) who responded as "very likely" that cooperative programs resulted in positive development (Figure 2). Even though respondents perceived positive benefits from both types of programs, it is clear they were more supportive of those that utilize cooperative philosophies and practices. 
$\square$ Competitive Activities

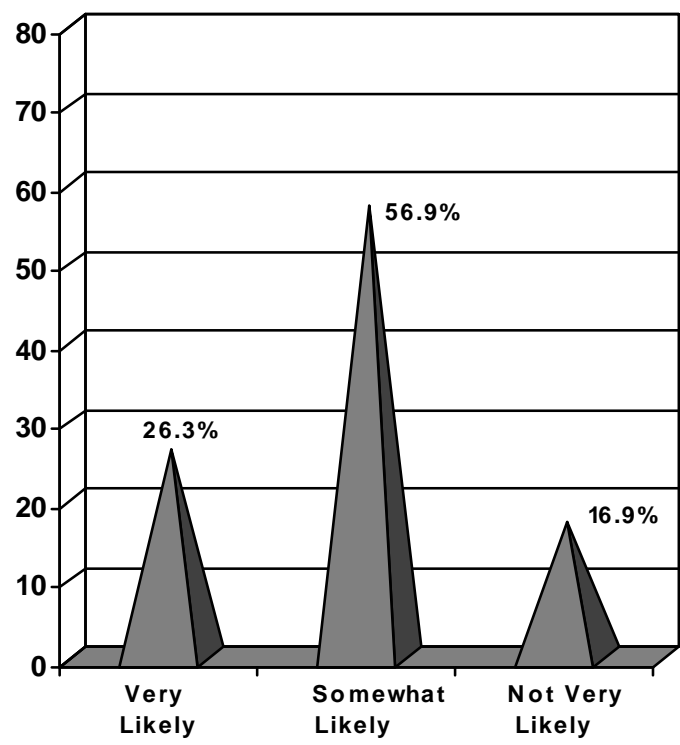

Figure 1. Likelihood of positive youth development with competitive activity structures

\section{Cooperative Activities}

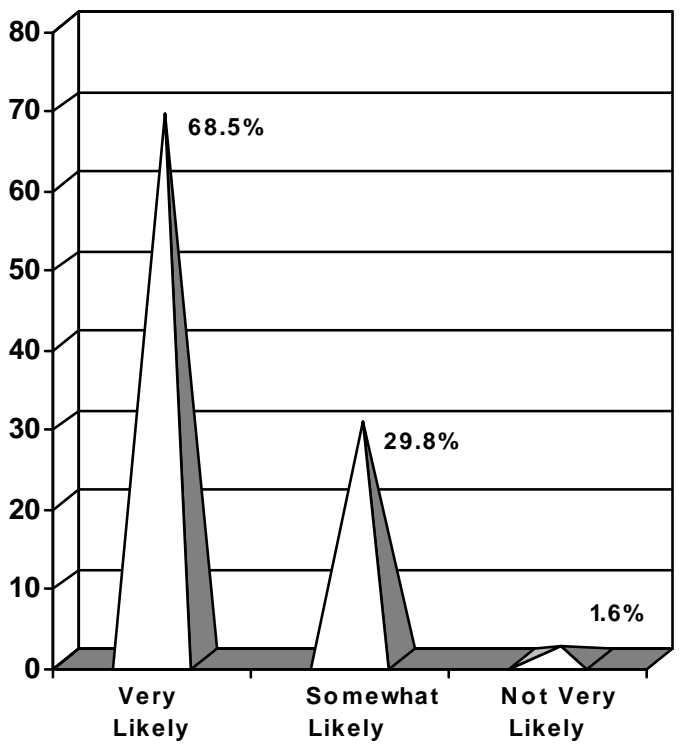

Figure 2. Likelihood of positive youth development with cooperative activity structures

\section{Discussion}

The findings point toward overwhelming public support for non-school youth development programs. Public opinion of youth programs was viewed as "very important" for promoting youth development. In regards to the perceived effectiveness of youth programs for preventing adolescent problem behaviors, a majority of the sample thought youth programs were "somewhat effective."

This is the first known investigation which has examined public opinions about the influence of program activity structure for positive youth development. The study found cooperative structured activities (youth working together) were selected by almost $75 \%$ of the respondents as compared to competitive-oriented activities (youth compete against each other) as having the most positive results for youth development. These findings are interesting since it is often believed U.S. cultural values are competitive-oriented from organized youth sports to nonschool programs or events, such as fair or show competitions. This finding corresponds to the research literature that has established the benefits of cooperative learning environments for positive youth development in relation to competitive or individual learning contexts (Ames, 1981; Ginsburg-Block, Rohrbeck, \& Fantuzzo, 2006; Johnson, D.W. \& Johnson, R.T., 1989; 1992; Junge, Manglallan, \& Raskauskas, 2003).

Demographic variations were minimal indicating a fair degree of uniformity in public opinion. For differences greater than $10 \%$, some of the notable findings included females perceiving cooperative-structured programs more often (about $11 \%$ ) than males for having the most positive results in youth programs. However, the research literature is mixed in the area of sex differences for cooperative or competitive preferences (Cabrera, Crissman, Bernal, Nora, Terenzini, \& Pascarella, 2002; Knight \& Chao, 1989). Also for the demographic variables of marital status and location, respondents who were divorced/separated and from the farm/open country perceived youth programs as "very important" for youth development as compared to single/never married respondents from the suburbs. 


\section{Conclusion}

The implications of these findings are encouraging for youth development organizations to argue for continued or increased funding of their programmatic efforts. Positive public perception of youth programs are essential as federal, state, and local officials make decisions about appropriating funds in a climate where social and human-related services efforts are often the first to be reduced or eliminated. In addition, programs focusing on positive youth development outcomes should consider activity structures that follow cooperative learning strategies, which are not only supported by evidence-based research, but by public opinion as producing more positive results for youth development than competitive-structured environments.

We recommend additional research on public perceptions of youth-programming, as one limitation of this study is its focus on only one state. Further, we strongly encourage additional research on perceptions of program importance, effectiveness, and activity structure among other key stakeholder groups, especially community leaders, parents, volunteers and program leaders/practitioners. Their support is vital for effective programming and should not be ignored.

\section{References}

Alder, J. (October 24, 2006). Sports parents gone bad. About: Sports \& recreation. Retrieved from http://football.about.com/b/a/257882.htm.

Ames, C. (1981). Competitive versus cooperative reward structures: The influence of individual and group performance factors on achievement attributions and affect. American Educational Research Journal, 18, 273-87.

Benson, P. L. (1997). All kids are our kids: What communities must do to raise caring and responsible children and adolescents: San Francisco: Jossey-Bass.

Cabrera, A. F., Crissman, J. L., Bernal, E. M., Nora, A., Terenzini, P. T., \& Pascarella, E. T. (2002). Collaborative learning: It's impact on college students' development diversity. Journal of College Student Development, 43(1), 20-34.

Callahan, D. (2004). The cheating culture: Why more Americans are doing wrong to get ahead. Orlando, FL: Harcourt.

Catalano, R. F., Berglund, M. L., Ryan, J. A. M., Lonczak, H. S., Hawkins, J. D. (2004). Positive youth development in the United States: Research findings on evaluations of positive youth development. The Annuals of the American Academy, 591, 98-124.

Deschenes, S., McDonald, M., \& McLaughlin, M. (2004). Youth organizations: From principles to practice. In S. F. Hamilton \& M. A. Hamilton (Eds.), The youth development handbook (pp. 25 50). Thousand Oaks, CA: Sage.

Dillman, D. A. (1978). Mail and telephone surveys: The total design method. New York: John Wiley \& Sons. 
Dillman, D. A. (2000). Mail and Internet surveys - The tailored design method. New York: John Wiley \& Sons.

Donnermeyer, J. F. (2000). Parents' perceptions of a school-based prevention education program. Journal of Drug Education, 30(3), 325-342.

Hein, K. (1998). Youth as resource. Grant Foundation Annual Report. New York: William T. Grant Foundation.

Ginsburg-Block, M. D., Rohrbeck, C. A., \& Fantuzzo, J. W. (2006). A meta-analytic review of social, self-concept, and behavioral outcomes of peer-assisted learning. Journal of Educational Psychology, 98(4), 732-749.

Johnson, D. W., \& Johnson, R. T. (1989). Cooperation and competition: Theory and research. Edina, MN: Interaction Book Co.

Johnson, D. W., \& Johnson, R. T. (1992). Preparing children to live in an interdependent world. In A. Combs (Ed.), Cooperation: Beyond the age of competition, (pp. 193-202). Philadelphia, PA: Gordon and Breach.

Junge, S. K., Manglallan, S., \& Raskauskas, J. (2003). Building life skills through afterschool participation in experimental and cooperative learning. Child Study Journal, 33(3), 165-174.

Knight, G. P., \& Chao, C. (1989). Gender differences in the cooperative, competitive, and individualistic social values of children. Motivation and Emotion, 13(2), 125-141.

Kress, C. (2004). Essential elements of 4-H youth development. Washington, DC: Retrieved March 10, 2005 from http://www.national4-hheadquarters.gov/library/elements.ppt

National Research Council and Institute of Medicine (2002). Community programs to promote youth development. J. Eccles \& J. A. Gootman (Eds.). Board on Children, Youth, and Families, Division of Behavioral and Social Sciences and Education. Washington, DC: National Academy Press.

Perkins, D. F., \& Borden, L. M. (2003). Key elements of community youth development. In Villarruel, F. A., Perkins, D. F., Borden, L. M., \& Keith, J. G. (Eds.), Community Youth Development: Programs, policies, and practices (pp. 327-340). Thousand Oaks, CA: Sage Publications.

Perkins, D., Borden, L., \& Villarruel, F. (2001). Community youth development: A partnership for action. School Community Journal, 11, 39-56.

Pittman, K. (2006). Balancing the equation: Communities supporting youth, youth supporting communities. Retrieved February 14, 2006 from

http://www.forumfyi.org/Files/balancingequation.pdf

Pittman, K., Irby, M., \& Ferber, T. (2000). Unfinished business: Further reflections on a decade of promoting youth development. Washington, DC: Forum for Youth Investment. 
Roth, J., Brooks-Gunn, J., Murray, L., \& Foster, William (1998). Promoting healthy adolescents: Synthesis of youth development program evaluations. Journal of Research on Adolescence, $8(4), 423-459$.

Scheer, S. D. (1997). Program parameters for 5- to 8-year-old children in 4-H. Journal of Extension [On-line], 35(4). Available at: http://www.joe.org/joe/1997august/a2.html.

Small, S., \& Memmo, M. (2004). Contemporary models of youth development and problem prevention: Toward an integration of terms, concepts, and models. Family Relations, 53(1), 311.

Zeldin, S., \& Topitzes, D. (2002). Neighborhood experiences, community connection, and positive beliefs about adolescents among urban adults and youth. Journal of Community Psychology, 30(6), 647-669.

(C) Copyright of Journal of Youth Development Bridging Research and Practice. Content may not be copied or emailed to multiple sites or posted to a listserv without copyright holder's express written permission. Contact Editor at: patricia.dawson@oregonstate.edu for details. However, users may print, download or email articles for individual use. ISSN 2325-4009 (Print); ISSN 2325-4017 (Online) 